\section{Pluralism and Economic Education: a Learning Theory Approach}

\section{Abstract}

Preparing students to participate in social and economic life after graduation is a widely held goal of economics instructors. How that goal is achieved and interpretations of what is a relevant skill, however, are a source of debate, covering both content coverage and pedagogical practices. This paper argues that a more pluralistic approach to both course content and pedagogy is fundamental for better preparing economics students for the world, and that learning theory is an integral component of understanding how to design practices to achieve desired outcomes.

\section{Introduction}

The longstanding question of 'what is it that we want our students, at the end of their studies, to know and be able to do?' (O'Donnell, 2002: 1) continues to challenge the economics profession. While preparing students to participate in social and economic life emerges as a widely held goal, interpretations of what this means for knowledge and skill acquisition vary widely. From a pluralistic perspective, exposure to multiple paradigms underlies debates on appropriate content coverage, while the extent to which faculty should move away from lectures and embrace active learning exercises lies at the heart of pedagogical discussions. While these two components are often discussed in isolation, some have argued that they are not independent. We agree that content and pedagogy are interconnected, and argue that 'pedagogical review (rather than mere curricula/topic adjustment) provides a stronger foundation to achieve the necessary content transformation to promote a pluralistic agenda'. ' Further, we make the argument that grounding the discussion in learning theory is key to developing this foundation.
Our review of existing literature suggests that calls for pluralism in economic education typically focus on economic content and range from discussions of comprehensive curricular reform to those focused on a single course or specific topic. While enriching the discussion among pluralistic economists, these arguments often fail to resonate with a broader audience, one that reaches beyond the heterodox tradition. We argue that efforts to bring pluralism to a broader audience will be strengthened by more effective use of expected learning outcomes - explicitly addressing what is desired (in terms of both content and skills), how it can be measured (quantitatively and qualitatively), and how it is to be achieved (through pedagogical practices which promote desired outcomes). This process begins with recognition that the pluralism debate is not simply one to be conducted by professionals at academic meetings; rather, the call to broaden economic content and classroom practices has roots in what outcomes students, faculty and employers desire. It also recognises that learning theory is an integral component of understanding how to design practices that generate desired outcomes.

Consequently, this paper provides a new perspective on the pluralism debate, focusing on using learning theory to design courses which explicitly include a consideration of learning outcomes. We begin with a brief overview of relevant economics literature, and argue that a more explicit and comprehensive use of learning theory will further the pluralistic agenda in economic education. We illustrate advantages of this approach through backward course design, a process that begins with identification of outcomes desired to guide the introduction of content and pedagogical practices to achieve these outcomes. We argue that this method of course construction is useful in furthering the pluralistic agenda because it explicitly links content and pedagogical choices to desired outcomes and allows for changes to be made incrementally, thereby moderating implementation costs to faculty.

\section{Pluralistic perspectives in economics education}

Previous arguments in support of a pluralistic perspective in economics education vary in focus and approach. While some authors have presented a more theoretical justification for broadening content coverage and pedagogical practices, others have gone the route of describing a single course or topic area in their quest to promote pluralism in economic education. A brief review of this work provides a logical starting point for our argument that explicitly grounding economic education reforms in learning theory provides a stronger basis for developing courses and curriculum that are consistent with a pluralistic perspective.

Aerni et al. (1999) employ stages of pedagogical development and course content revision as a means of creating a more inclusive classroom. Pluralism from this 
perspective is grounded in their statement that 'if the goals of economics education include increasing students' understanding of the world and enabling them to participate fully as citizens in a democratic society, then the economics classroom must invite all students to participate'(Aerni et al., 1999: 29). This inclusive classroom environment is generated by transitioning from individual learning to group learning and ultimately to learning communities. Supportive content revisions begin at the point of teaching the received neoclassical canon, then finding and adding heretofore underrepresented groups, which leads one to challenge core concepts and propose alternatives, culminating in redefining and reconstructing economics to include everyone (Aerni et al., 1999: 32). Perhaps what is most intriguing about this perspective is that it explicitly argues that progression in one area (either content or pedagogy) will lead to progression in the other.

By way of an introduction to a new section on pedagogy in the Review of Radical Political Economics, Dorman (2002) presents the argument that greater focus on pedagogy in the political economy approach to economics is needed. He describes the importance of reconciling classroom practices with broader political economy research agendas, developing an argument for a pluralistic economic education. While this perspective is presented in the context of the philosophy of John Dewey and Paulo Freire, many will recognise key elements as consistent with frameworks put forth by both Bloom (1956) and Perry (1970).2 Specifically, Dorman argues that the classroom is a social setting in which learning occurs when ideas are shared and challenged, that people construct their own understanding and learn more effectively in groups, that no idea can be appreciated apart from an encounter with its 'other', that education comes from experiences and critical thinking requires challenging of perspectives, and that problem-solving skills need to be developed (Dorman, 2002:489-90).

In contrast to the two previous articles that focus on pedagogical changes with links to learning theory in their arguments for a pluralistic economic education, others have focused on changes in content. Barone (1991:18) suggests that teaching contending perspectives provides students with exposure to a wider range of economic phenomena and human values underlying economic actions so students develop evaluative skills and thus are better prepared to assess policy choices. Mearman (2007) describes three well travelled strategies for incorporating heterodox content: the orthodox-plus approach, teaching from a heterodox perspective and using a parallel perspectives approach. He argues that teaching multiple perspectives enhances student learning because it provides them with a better understanding of orthodoxy and economic policy, encourages expanding the domain of economics and better prepares students for complexity that is present in the world beyond the classroom walls.
In addition to general arguments advancing pluralism described above, furthering the pluralistic perspective in economics also targets individual courses. While not specifically focused on heterodox economics, Borg and Borg (2001) use a Perry framework for defining critical thinking and describing how reliance on a single perspective can limit students' intellectual development to dualistic thinking. They use this standpoint to argue for interdisciplinary approaches to teaching economics. Knoedler and Underwood (2003) build on this framework in support of a multi-paradigm approach to principles courses arguing that it provides students with a useful way to understand the actual economy. Using a constructivist approach applied to topics covered in introductory, radical political economy, and urban courses, Ford and Leclerc (2000) argue for explicitly identifying and building on student knowledge and understanding generated through experiences, providing a basis for comparing alternative perspectives. Ford et al. (2007:300) describe additional examples of the constructivist approach, further arguing that it 'relies on the students' own experiences to provide "scaffolding" for the student to construct an increased understanding of economic phenomena'.

In response to Dorman's call for examples of teaching methods consistent with the political economy approach, Banks et al. (2005) use a particular pedagogical method (service-learning) and a specific economic issue (the living wage) to address one of Dorman's key aspects of political economic education: that student experience matters. They argue that well defined service-learning experiences can 'lead to personal and social transformation' (Banks et al., 2005:348). McGoldrick and Peterson (2009) introduce the concept of public scholarship, applied within a social economics perspective, as a method of generating deeper learning by using an intentional learning process as students take ownership over their own learning. Public scholarship activities are grounded in community problems and therefore 'transcend traditional (academic) understanding of social and economic problems' (McGoldrick and Peterson 2009:232). Course projects are described which integrate students' service to the community, course content, class discussion and research, in two courses in Women in the Economy, in two very different institutional settings.

Maier (2008) adds a unique perspective to the discussion, addressing three 'research traditions' which have potential to contribute to the pluralistic agenda. Specifically, overviews and examples associated with the Perry framework of intellectual development, structured cooperative learning, and research in the learning sciences are used to demonstrate methods of incorporating pluralism in economics courses. This work is the first to explicitly integrate key learning science developments associated with constructivism (identifying current knowledge and perspectives as a key step in understanding alternative perspectives), 
metacognition (being conscious about one's own learning) and transfer (to new contexts) in a discussion of pluralism in economic education.

While this review of literature is by no means exhaustive, it highlights key steps taken in promoting pluralism to a wider audience. McGoldrick (2009:222) argues that 'promoting pluralism in economic education requires a change in the status quo: the single paradigm, single delivery approach', and that any agenda for pluralism in economic education necessitates that learning goals be identified and incentives provided. She identifies existing incentives that are growing in strength as evidenced by the liberal education movement and public calls for better assessment of the impact higher education practices have on learning. Perhaps most important for our perspective, however, is the recognition that learning goals and incentives have roots in a more rigorous consideration of learning theory, outcomes and practices. In this light, we employ student engagement and the theory of significant learning to motivate practices that generate learning outcomes which are more pluralistic in nature.

\section{Student engagement}

Although literature on pluralism in economic education presents a wide range of views on where and how reforms should take place, connections between increasing 'student engagement' and more pluralist approaches are common throughout. For example, it is argued that reforming economics course content to be more inclusive of different society members experiences will engage a more diverse student body in the subject of economics because they can see themselves and the issues they care about as part of the discussion (Aerni, et al., 1999). Students will also be better prepared to understand 'that economic choices have moral dimensions' (Barone 1991:18), engaging their hearts as well as their minds. Further, by critically evaluating assumptions and teaching alternative approaches, pluralistic approaches make economics better reflect the world that students actually observe, thus engaging their interest (Mearman, 2007; Knoedler and Underwood, 2003).

A more pluralist approach to pedagogy is also linked closely with increased student engagement. For example, some authors identify the potential of group-based pedagogies to create richer environments for exploring pluralistic content by making the classroom more collaborative and cooperative (Aerni et al., 1999). The use of active learning and experiential exercises (such as cooperative learning, simulations, experiments and field work) also provides a way to capture student interest, question underlying assumptions and illuminate different approaches to economic analysis (Dorman, 2002; Mearman, 2007; Maier, 2008). Experiential pedagogies that involve students in the community - including service-learning and public scholarship - have the potential to connect students' lives with course material and community issues, providing a catalyst for enhanced future community engagement (Aerni, et al., 1999; Banks, et al., 2005; McGoldrick and Peterson, 2009).

'Student engagement' emerges from the economics literature as a process that creates an environment conducive for pluralism, and 'engaged learning' becomes a goal in the pursuit of education with a higher purpose. Bowen $(2005: 4,7)$ identifies four different but related meanings of engagement, all of which are currently employed in the literature on pluralism in economics:

- The most fundamental meaning of engagement is 'student engagement with the learning process'. While this is most typically associated with active learning, it reaches beyond enhanced content comprehension as students become more reflective on behaviours that enhance their learning.

- The second meaning of engagement is 'student engagement with the object of study', where students learn by 'direct experience of something new'. This draws on the tradition of experiential learning and is grounded in applications with real world interactions.

- The third meaning of engagement is 'student engagement with contexts of the subject of study'. This approach, typically associated with multi-disciplinary learning, includes consideration of social and civic contexts of the subject, and associated ethical issues as students practice integrating their knowledge across courses and subjects.

- Finally, there is 'student engagement with the human condition, especially in its social, cultural and civic dimensions'. This engagement is pursued through activities such as service-learning in which students interact with others unlike themselves, gaining a deeper understanding of themselves and others.

Bowen (2005:7) concludes that, taking into account the various meanings of engagement, engaged learners are 'those who complement and interpret what they learn from others with direct knowledge based on personal experience, who develop appropriately complex understandings situated in relevant contexts, and who recognize learning's moral implications and consequences'. The most important contribution of engagement is 'the focus it brings to the learner's personal relationship to learning', a necessary component of learning that lasts.

The role of engagement in the literature on pluralism in economic education is revealed in this context. Approaches focusing on reforming content exemplify student engagement with the context of study, emphasising alternative perspectives. Reforming content may also actively engage students in the learning process through questioning and critical evaluation of assumptions. Approaches 
promoting pluralism through pedagogical practices such as the use of cooperative learning, simulations, experiments and field work to illustrate key concepts and question established analyses exemplify both active learning and experiential learning. And the use of service-learning as a way to promote pluralism exemplifies student engagement with the human condition.

\section{Significant learning}

In the preceding paragraphs we established connections between promoting engagement and pluralism, regardless of whether the source of broadening perspectives is initiated via changes in course content or pedagogical practice. We introduced an array of engagement definitions to argue that existing literature promoting pluralism in economics already embraces tenets of engagement. We now use this background as scaffolding to link desired outcomes associated with pluralism to the theory of significant learning through the process of backward course design. This will serve as grounding for examples demonstrating how using learning theory provides a stronger basis for promoting pluralism in economic education.

Economic educators have struggled to find evidence that the learning we assume is occurring in our courses has any lasting effect. ${ }^{3}$ Education literature provides insights into this 'learning and forgetting' behaviour suggesting that 'we can only learn from activities that are interesting and comprehensible to us, in other words, activities that are satisfying. If this is not the case, only inefficient rote learning, or memorization, is available to us and forgetting is inevitable' (Smith, 1998: 87). Marton, et al. (1997: $x$ ) argue that the quality of learning is enhanced when the 'student seeks a personal understanding' of the material, referred to as a deep approach to learning, as opposed to a desire to simply regurgitate material as exemplified by a surface approach to learning. In short, it is necessary to go beyond a simple transmission of knowledge and include broader objectives in the development of course goals.

Throughout existing literature promoting pluralism in economic education, increasing student engagement with the learning process, the subject and its contexts, and the community, contribute to achieving course goals that go beyond mastery of standard economic concepts. Promoting a more pluralist approach through engaged learning increases 'students' understanding of the world' and enables 'them to participate fully as citizens in a democratic society' (Aerni et al., 1999: 29), builds students' 'mental and emotional skills for problem solving' (Dorman, 2002: 490), leads to 'individual moral and ethical development' as students 'explore their own values and values of others' (Barone, 1991: 18), fosters the development of 'key cognitive skills as well as open-mindedness and tolerance'
(Mearman, 2007:6), provides 'students a useful way to understand the actual economy' (Knoedler and Underwood, 2003: 701), requires them to take 'ownership over their learning' (McGoldrick and Peterson, 2009: 241) and 'engender[s] personal change'(Banks, et al., 2005: 348).

The question remains, however, how to develop activities that engage students in ways that promote deep approaches to learning and generate desired outcomes. Fink (2003) provides one avenue for developing courses in which the experience of learning ${ }^{4}$ matters as much as associated activities in moving students beyond rote memorisation, identifying six categories associated with 'significant learning':

- Foundational knowledge: Provides 'the basic understanding that is necessary for other kinds of learning' (Fink, 2003:31). This encompasses understanding and remembering information and ideas.

- Learning how to learn: Learning about the learning process in a way that enables students to become better students, inquire about a subject and construct knowledge, and become 'self-directing learners' (Fink, 2003:50-55).

- Application: Involves 'using foundational knowledge' and encompasses the development of different skills and thinking (critical, creative, and practical), as well as the ability to manage complex projects (Fink, 2003:38).

- Integration: Involves making connections between ideas, people, and realms of life (Fink, 2003:31).

- Human dimension: Refers to the process of learning about oneself and others, to 'inform students about the human significance of what they are learning' (Fink, 2003:31-32).

- Caring: Involves the 'development of new feelings, interests and values' (Fink, 2003: 74).

Student engagement provides a particularly powerful means to approach significant learning outcomes. One avenue for facilitating this approach employs a process of 'backward design'. Backward course design, as defined by Wiggins and McTighe (2005:17-19) reverses the traditional process of course development instead of starting with decisions about reading materials and activities, instructors begin by asking what students should 'walk out of the door and be able to understand, regardless of what text and activities we use?' This is followed by questions concerning assessment, asking 'how will we know if students have achieved the desired results?' Only after these two steps are completed does course design turn to planning instruction, asking 'what enabling knowledge (facts, concepts and principles) and skills (processes, procedures, strategies) will students need in order to perform effectively and achieve desired results?' 
In the final step of backward course design, student engagement becomes a valuable strategy for promoting pluralism in the context of desired learning outcomes. Backward course design can link efforts to promote pluralism through increased engagement to learning outcomes by providing a process through which priorities can be determined and changes in content and pedagogy focused. It can also help instructors committed to promoting pluralism in economics to avoid falling into the trap of overwhelming students with simply more content and/or more activities.

\section{Abbreviated demonstrations of using significant learning theory to} achieve outcomes consistent with the pluralistic approach

Choosing pedagogical practices through which the instructor addresses categories of significant learning is a critical step in developing learning that lasts. In this section we provide examples grounded in two pedagogical practices which are not widely used in economics - cooperative learning and service-learning. Our goals are to demonstrate how these can be used to develop significant learning outcomes that move beyond traditional foundational knowledge, and provide examples which allow for incremental changes in course design, while also reinforcing and developing pluralist perspectives in economics.

\section{Cooperative learning}

Cooperative learning exercises provide a wide range of activities to engage students in the learning process while developing deeper appreciation for multiple perspectives. Such exercises promote an environment in which the learning of one student is enhanced by contributions of all group members, individuals are motivated to take responsibility for contributing to learning within the group, no member can avoid contributing during the exercise, and many groups are engaged in the activity simultaneously (Kagan, 2009). Cooperative learning exercises range from quick and informal to encompassing entire class periods with very formal components. Thus, exercises can be developed for any economics class from introductory to senior experience courses as well as survey, mathematical and theoretically oriented courses. Backward course design, with its emphasis on learning objectives, provides a process for choosing amongst these strategies.

Note-taking pairs are a cooperative learning application focused on helping students learn how to learn. Note-taking pairs are a form of the common think-pair-share exercise, where students compare and critique their own notes through a structured process which enhances their ability to identify key information, gauge holes in their understanding and engage in conversations that use economic language. This is an especially useful technique when students are faced with competing perspectives and are challenged to identify and explain key differences including underlying assumptions. Consider an example in which the instructor has completed a 'compare and contrast' lecture that introduces students to neoclassical and institutional perspectives. The first student in the pairing uses their notes to identify key assumptions underlying the neoclassical perspective. The second student listens, asks for clarification and compares what is said to their notes, filling out missing details. The order then reverses and the second student leads with a description of the institutionalist perspective. After the exercise, the class can have a more focused conversation addressing remaining issues and building on shared knowledge. This exercise takes relatively little class time as students first vet their understanding rather than simply asking the instructor to rehash the material in response to the open ended 'any questions' invitation.

An advantage of cooperative learning as a pedagogical practice is that it provides a diverse set of paths for incremental development of significant learning categories. Although the example above focused on the category learning how to learn, the vast array of existing cooperative learning strategies 5 provide sufficient flexibility so that different learning outcomes can be addressed throughout a course. For example,'cooperative controversy' - 'a process that helps students identify and evaluate multiple perspectives on an issue' (Maier, et al., 2010) - focuses on significant learning outcomes of application and integration. ${ }^{6}$ One half of a class is assigned an article providing one perspective on a topic such as the minimum wage while the other half reads an article supporting a contrary perspective. Students are first paired up with another having read the same article and are directed to take turns identifying key argument components. Once students develop a level of expertise with one perspective, they are subsequently grouped with a pair of students who have identified key arguments from the alternative perspective. Again, taking turns, they explain alternative arguments. Students finish the exercise by identifying strong and weak arguments for both perspectives.

\section{Service-learning}

We now turn to a pedagogical practice, service-learning, that is more holistic in addressing categories of significant learning. Service-learning:

is a strategy that builds character, spurs civic engagement, and applies content to abstract theories, allowing teachers to engage students as active participants in the learning process. Instead of simply asking students to open their textbooks, teachers using service-learning engage students in a critical thinking exercise to examine their world. Students are guided to 
connect their interests and moral leadership to solve a problem, serve a need, or be of service to others. Once a focus for service is identified, students may apply skills such as data collection, documentation,

problem-solving, charting and graphing, and persuasive writing to test theories, develop surveys, analyze data, inform community decision-makers, and practice communication skills (Pearson, 2002:6).

Through service-learning activities students 'integrate their study of economics in the classroom with service activities in their communities, 'both improving their knowledge of economics and the quality of their communities (McGoldrick and Ziegert, 2002:1). Service-learning is a flexible pedagogical technique that can be incorporated into economics courses in multiple ways and with varying levels of complexity. Service-learning projects may, for example, be used as an assignment to address a particular economic topic, or may provide 'the basis for the entire context of the course' (Ziegert and McGoldrick, 2008: 45).

The connections between service-learning activities and learning outcomes have been generated through discipline specific research, 7 but are nicely illustrated by Howard's (1993:48-49) description of the 'features of service-learning'They provide a useful framework for linking service-learning with significant learning outcomes and meanings of engaged learning discussed above:

- Develop foundational knowledge: Service-learning promotes the acquisition of foundational knowledge, because 'service experiences are valuable sources of knowledge and valuable resources for scholarship'.

- Learn inductive reasoning: Service-learning experiences also help students learn how to learn. Students become engaged with the learning process through the development of inductive reasoning - 'by using the specific as an embarkation point for hypothesizing and theorizing'.

- Apply knowledge, critically think and analyze:Through their experiences in the community, service learners apply knowledge 'by testing and applying academic learning,' and engage in critical thinking and analysis' by learning to distinguish what is and isn't important in the unfiltered context of the real world'.

- Synthesise knowledge:Through service-learning experiences, students have the opportunity to integrate their learning from different situations and disciplines, and to synthesise knowledge by 'bringing together past and present learning'.
- Learn about cultural diversity:Through service-learning experiences, students engage with the human experience and learn about themselves and others. In particular, students gain opportunities to learn about cultural diversity, 'by learning with, from, and about people of other races, ages, economic means, and competencies'.

- Develop values: Service-learning may also foster caring and the development of new values, through students' ffirst hand interaction with community issues'

The connections between outcomes of engaged learning, significant learning, pluralistic economics and service-learning are outlined in Table 1. In the following sections, we provide two examples to demonstrate how service-learning can facilitate pluralistic revisions of course content and address selected outcomes (table rows) for a particular topic or an entire course. Our first example describes the use of service-learning focusing on a particular topic - the living wage - to address significant learning categories of the human dimension and caring. We then summarise a series of service-learning experiences designed for Women in the Economy courses and indicate their connections to the significant learning category of integration.

Table 1. Integrating engaged learning, significant learning, pluralism and service-learning outcomes

\begin{tabular}{|c|c|c|c|}
\hline $\begin{array}{l}\text { Engaged } \\
\text { Learning } \\
\text { (Bowen, 2005) }\end{array}$ & $\begin{array}{l}\text { Significant } \\
\text { Learning } \\
\text { (Fink, 2003) }\end{array}$ & $\begin{array}{l}\text { Identified Pluralistic } \\
\text { Outcomes (various } \\
\text { authors as noted in text) }\end{array}$ & $\begin{array}{l}\text { Service-Learning } \\
\text { Outcomes } \\
\text { (Howard, 1993) }\end{array}$ \\
\hline $\begin{array}{l}\text { 'Teachers strive } \\
\text { to produce } \\
\text { engagement } \\
\text { as a means to } \\
\text { learning' }\end{array}$ & $\begin{array}{l}\text { Foundational } \\
\text { Knowledge }\end{array}$ & $\begin{array}{l}\text { 'students' understanding of } \\
\text { the world' } \\
\text { 'key cognitive skills' } \\
\text { 'a useful way to understand } \\
\text { the actual economy' } \\
\text { 'understand orthodoxy' } \\
\text { '... building off his or her } \\
\text { knowledge and understanding... } \\
\text { 'better understanding of } \\
\text { economic policy' }\end{array}$ & $\begin{array}{l}\text { Foundational } \\
\text { Knowledge }\end{array}$ \\
\hline $\begin{array}{l}\text { Student } \\
\text { engagement } \\
\text { with the learning } \\
\text { process } \\
\text { (active learning) }\end{array}$ & $\begin{array}{l}\text { Learning How } \\
\text { to Learn }\end{array}$ & $\begin{array}{l}\text { 'develop evaluative skills' } \\
\text { 'actively engage participants } \\
\text { in the learning process' } \\
\text { 'people construct their own } \\
\text { understanding' } \\
\text { 'generating deeper learning' } \\
\text { 'intentional learning process' }\end{array}$ & $\begin{array}{l}\text { Learn inductive } \\
\text { reasoning }\end{array}$ \\
\hline
\end{tabular}


Table 1. (continued) Integrating engaged learning, significant learning, pluralism and service-learning outcomes

\begin{tabular}{l} 
Engaged \\
Learning \\
(Bowen, 2005) \\
\hline Student \\
engagement \\
with the object \\
of study
\end{tabular}

(experiential

Student

engagement

with contexts

(multidisciplinary

learning)

\section{Student}

engagement

with the human

condition

(service-learning)

'Perhaps the most Caring important

contribution of

engagement is

the focus it brings

to the learner's

personal

relationship to

learning.'

\section{Significant}

Application

\section{Identified Pluralistic Outcomes (various} authors as noted in text)

Service-Learning

Outcomes

(Howard, 1993)

participate fully as citizens

in a democratic society'

'catalyst for enhanced future

community engagement'

Apply

knowledge,

'provide 'scaffolding' for the

critically think

learning)

student to construct an

increased understanding'

'.... addresses community

problems and transcends

traditional understandings of

social and community problems.'

Integration 'expand the domain of Synthesise

economics'

knowledge

'expose them to a greater variety

of economic phenomena'

'integrates students service to

the community, course content

and class discussion, and

student research papers'

'argue for interdisciplinary

approaches to teaching economics'

'open-mindedness and tolerance' Learn about

'classroom is a social setting'

'a more diverse student body'

'range of human values

underlying human economic

action and choice'

'... no idea can be appreciated apart from an encounter with its "other".'

'lead to personal and social

transformation'

Develop values

'engender personal change'

'explore their own values and

the values of others'

'student ownership over their

learning...'

'economic choices have mora

dimensions'

'mental and emotional skills

for problem solving'

\section{Service-learning and the living wage}

Banks et al. (2005) describe a service-learning exercise structured around a living wage research project in 'radical political-economy-based' courses at two different institutions. The service-learning techniques illustrated reflect the spirit of

backward course design, as course activities address the goals of significant learning outcomes and a more pluralistic treatment of economics:

Implementing service learning in a course offers the promise of encouraging higher order analytical and creative learning for all concerned, and it promises the type of civic engagement in real world problems that can be valuable in teaching political economy (Banks et al., 2005:347).

Under the guidance of a political economy approach, living wage project activities engage students in the learning process by challenging them to 'think differently about the world' (Banks et al., 2005: 354) and to question the absence of history, power and human agency in neoclassical theories of wage determination. Further, by promoting 'an alternative, ethically based vision of the world that deviates from the neoclassical acceptance of wages that are insufficient to meet human needs' (Banks et al., 2005: 354), the living wage project supports students' engagement with the human condition and development of values and caring.

The living wage project implemented at one institution began with students listening to and assessing the needs of a very local community, the low-wage support staff workers at their own university. As they learned about economic circumstances and struggles of these workers, students also read and discussed broader historical and theoretical literature. Student groups investigated aspects of the problem, including wages, benefits and working conditions on campus and in the local community, the cost of living in the local community and in neighbouring communities, and activities of other living wage campaigns. Ultimately, students estimated a living wage value and were able to 'determine precisely how many university employees earned less than a living wage' (Banks et al, 2005: 351). Based on their research, and after 'considerable debate,' the students recommended a particular hourly wage:

In many ways, this decision embodied so much of the service learning for this course. They sought input from support staff people, debated political versus economic reality, discussed how many people one full-time income could support, and considered how they might best make a contribution to what they had come to believe was a fair and just demand for a living wage. Their reflection drew on course literature, interaction with many people in the community, and a clarified understanding of power relations in society and what these mean for real people who earn low wages (Banks et al., 2005:351). 
These course outcomes exemplify significant learning outcomes of the human dimension, where students realise 'the human significance of what they are learning', and caring, where students develop 'new feelings, interests and values'(Fink, 2003:

31-32,74). Through service-learning experiences, students evaluated their own campus and local community in a new light, and learned from people in circumstances much different from their own. Students had the opportunity to learn about economic and cultural diversity and to develop new values through their 'first hand interaction with community issues' (Howard, 1993:49), thus promoting 'civic engagement in real world issues' (Banks et al., 2005: 347).

\section{Service-learning and Women in the Economy courses}

The first documented service-learning application employed this pedagogical technique in a Women and Gender Issues in Economics course to link abstract classroom theories to the world beyond university grounds (McGoldrick, 1998). Focusing on the issue of poverty, students participated in a range of activities at organisations that spanned the spectrum of the cycle of poverty. Multiple forums were provided to'validate the learning experiences of the students, provide the opportunity for them to hear other students' perspectives of their learning process, and link the work of many community organizations on a single economic issue (McGoldrick, 1998: 371).

The service-learning component of a Women and Work elective course described by Figart and Olsen (2002: 227) engaged students in an analysis of workplace dynamics using research by feminist economists to 'broaden the scope of economic discourse, theory and methodology ....'Unlike the service-learning application described above, however, volunteer activities themselves were not the focus of learning experiences; rather, students' volunteer time allowed them to identify and 'observe gender relations in the workplace' including those linked to discrimination, segmentation and resistance strategies. Reflective journals and term papers helped '[s] ervice learning students [identify] the connection between their experiences, the sociological literature on emotional labor, and the economic studies that document the wage penalty associated with female-dominated occupations' (Figart and Olsen 2002: 229).

More recently, McGoldrick (2008) demonstrates how backward course design generated a student driven project, using service-learning to investigate the demand for a child care centre on campus. Key to the development of this course project was the recognition 'that most students prefer to rely on either their business or women's studies background rather than using these to complement economic analysis. The challenge is to acknowledge student expertise in complementing subjects while developing their skills in using traditional economic analysis' (McGoldrick, 2008: 5). This was achieved through explicit discussions of how to incorporate related knowledge pertaining to both issues covered and projects undertaken in courses across the institution.

McGoldrick and Peterson (2009:234,242) present a complementary motivation for using service-learning in two Women in the Economy courses: developing projects consistent with tenets of public scholarship. In one course, traditional service-learning activities were enhanced to allow for the '... recognition that knowledge is generated in and by the community as well as by teachers and students of the university, through a process that integrates the university's key functions of teaching, research and service'. The second course description focused on the process by which students claimed ownership over their learning. This transformation was demonstrated through many facets of public scholarship including '[c]onnections [that] went beyond the simple grounding of new results in established literature' including connections with text material, previous campus studies and various campus constituencies.

Despite this wide range of service-learning experiences, each example illustrates possibilities for achieving significant learning and pluralistic economic outcomes. The service-learning activities required students to engage in formal reflection, and through this reflective process service-learning became a means for integration, of theory with reality, course content with community problems, alternative perspectives from across disciplines and within economics, and with constituencies across the institution. This reflection was a forum for student expression, demonstrating growth beyond basic understanding of course content through engagement with others unlike themselves, developing a greater appreciation of the human condition and challenging their own values and ethical positions. In addition, each service-learning activity included a description of how course content was either implicitly broadened to include multiple perspectives as a result of students' experiences or explicitly broadened through materials used to place student experiences into perspective, thus promoting a more pluralistic perspective on economics.

\section{Conclusion}

We argue that efforts to promote pluralism in economic education could be strengthened by employing learning theory to provide scaffolding on which to generate significant learning experiences. We believe that the course development method described above is inherently pluralistic - enhancing the pluralistic nature of instruction is a necessary component of generating significant learning experiences. We introduce the process of backward course design as a method for developing courses that promote forms of student engagement to foster significant learning outcomes. In addition, we provide examples (topics and courses) which indicate that economists are, perhaps unknowingly, already 
developing experiences consistent with facets of this approach. We believe these experiences could be further enhanced if instructors embraced the entirety of the tenets of significant learning as developed through backward course design.

The advantage of this process is that it provides a method for systematically developing topics and courses. It allows faculty to incrementally enhance their teaching in ways that support both significant learning and pluralism. While examples provided were limited to cooperative learning and service-learning, other pedagogical practices such as experimental economics, discussion-based learning and the use of case studies also have potential for such incremental development. In other words, choosing a pedagogical practice with which the instructor is most comfortable is an important step in developing learning that lasts as each category of significant learning is incrementally developed.

As indicated in our introduction, the call to broaden classroom practices is not just a theoretical issue, but is of real concern to faculty, students and employers. As Fink (2003:4-5) reports, faculty want to teach students who are more engaged learners and students want courses where they can see the value of what is taught. Further, employers want better and more broadly educated workers, reporting 'teamwork and collaboration', 'applying knowledge to real world settings', 'integrity and ethics' and 'civic knowledge and participation, and community engagement' among the skills they would like to see emphasised more at the undergraduate college level (Jaschik, 2007). Clearly, the desires of faculty, students and employers are in line with the goals of significant learning. Grounding our efforts to reform economic content and pedagogy to better meet these goals in learning theory can strengthen these efforts and increase their impact on the profession, as well as enhance the development of a more pluralistic economic education.

\section{Notes}

1 We thank one of the reviewers for providing this language summarising a key motivation for this paper.

2 The frameworks of both Bloom and Perry provide insight into the intellectual development (cognitive domain) of students. Bloom identifies key mental skil categories of knowledge, comprehension, application, analysis, synthesis and evaluation. Perry described learning in terms of stages which begin with dualistic thinking, and advance toward multiplicity, contextual-relativism and making contextually appropriate decisions.

3 See for example, Saunders (1980) and Walstad and Allgood (1999).

4 A phrase coined by Marton et al. (1997).

5 See for example, Barkley et al. (2005).

6 See Maier (2008) on using cooperative learning to advance the pluralistic agenda.

7 See for example, AAHE's Series on Service-Learning in the Disciplines; Zlotkowski (1997-2000).

\section{References}

Aerni, A.L., Bartlett, R., Lewis, M., McGoldrick, K. and Shackelford, J. (1999) 'Towards a Feminist Pedagogy in Economics' Feminist Economics, vol. 5(1), pp. 29-44.

Banks, N., Schneider, G. and Susman, P. (2005) 'Paying the Bills is Not Just Theory: Service Learning about a Living Wage' Review of Radical Political Economics, vol. 37(3), pp. $346-356$.

Barkley, E.F., Cross, K.P. and Major, C.H. (2005) Collaborative Learning Techniques: A Handbook for College Faculty. San Francisco, CA: Jossey-Bass.

Barone, C.A. (1991) 'Contending Perspectives: Curricular Reform in Economics' Journal of Economic Education, vol. 22(1), pp. 15-26.

Bloom B.S. (ed.) (1956) Taxonomy of Educational Objectives, the classification of

educational goals - Handbook l: Cognitive Domain. New York: McKay.

Borg, J.R. and Borg, M.P (2001) ‘Teaching Critical Thinking in Interdisciplinary Economics Courses' College Teaching, vol. 49(1), pp. 20-29.

Bowen, S. (2005) 'Engaged Learning: Are We All on the Same Page?' Peer Review, vol.7(2), pp.4-7.

Dorman, P. (2002) 'Pedagogy and Political Economy' Review of Radical Political Economics, vol. 24, pp. 487-492.

Figart, D.M. and Olsen, B. (2002) 'What Can Volunteer Work Teach Students about the Study of Paid Work? A Discussion of a Women-and-Work Course', in K. McGoldrick and A. Ziegert (eds) Putting the Invisible Hand to Work: Concepts and Models of Service Learning in Economics, Ann Arbor, Ml: University of Michigan Press, 224-239.

Fink, D. L. (2003) Creating Significant Learning Experiences: An Integrated Approach to Designing College Courses, San Francisco, CA: Jossey-Bass.

Ford, E.J and Leclerc, D.C. (2000) 'A Constructivist Approach to College-Level Economic Education' Review of Radical Political Economics, vol. 32(3), pp. 482-494.

Ford, E.J., Leclerc, D.C. and Ford, D.J. (2007) 'A Constructivist Approach to Learning Unemployment' Review of Radical Political Economics, vol. 39(3), pp. 329-334.

Howard, J. (1993) 'Advocating for Community Service Learning at the University of Michigan', in Galura, J., Meiland, R., Moss, R., Callan, M.J., and Smith, R. (eds) Praxis Il: Service Learning Resources for University Students, Staff, and Faculty, Ann Arbor, Ml: University of Michigan, Office of Community Service Learning, pp. 34-59.

Jaschik, S. (2007) 'New Definition for Liberal Education' Inside Higher Education (11

January 2007). Retrieved September 2009 from http://www.insidehighereducation.com/ news/2007/01/11/aacu

Kagan, S. (2009) Cooperative learning. San Juan Capistrano, CA: Resources for Teachers, Inc Knoedler, J.T. and Underwood, D.A. (2003) 'Teaching the Principles of Economics: A Proposal for a Multi-Paradigmatic Approach' Journal of Economic Issues, vol. 37(3), pp. 697-725.

Maier, M. (2008) 'Pedagogy in the Pluralist Classroom' (Working Paper).

Maier, M., McGoldrick, K and Simkins, S. (2010) 'Implementing Cooperative Learning in Introductory Economics Courses', in B. Millis (ed) Cooperative Learning in Higher Education, Sterling, VA: Stylus Press.

Marton, F., Hounsell, D. and Entwistle, N. (eds) (1997) The Experience of Learning, Second Edition, Edinburgh: Scottish Academic Press.

McGoldrick, K. (1998) 'Service-Learning in Economics: A Detailed Application' Journal of Economic Education, vol. 29(4), pp. 365-376.

McGoldrick, K. (2008)'The Importance of Learning Objectives in Choosing Pedagogical Practices and Developing Assessment Strategies'. Presented at the Southern Economic Association Annual Meeting (November 2008), Washington, DC. 
McGoldrick, K. (2009) 'Pluralism and Economic Education, Promoting Change: Past Present, and Future', in Garnett, R.F., Jr., Olsen, E. and Starr, M. (eds) Economic Pluralism, Abingdon: Routledge.

McGoldrick, K. and Peterson, J. (2009) 'Public Scholarship and Economics: Engaging Students in the Democratic Process' International Review of Economic Education, vol. 38 (2), pp. 229-245

McGoldrick, K. and Ziegert, A. (eds) (2002) Putting the Invisible Hand to Work: Concepts and Models of Service Learning in Economics, Ann Arbor, Ml:University of Michigan Press.

Mearman, A. (2007) 'Teaching Heterodox Economic Concepts', in: Handbook for

Economics Lecturers, Economics Network. Retrieved September 2009 from

http://www.economicsnetwork.ac.uk/handbook/heterodox/

O'Donnell, R. (2002) 'What Kind of Economics Graduates Do We Want? A Constructive

Critique of Hansen's Proficiencies Approach'. Working Paper No 203, Macquarie

University, Department of Economics. Retrieved September 2009 from

http://www.econ.mq.edu.au/research/2002/3-2002_ODonnell.PDF

Pearson, S. S. (2002) Finding Common Ground: Service Learning and Educational Reform: A

Survey of 28 Leading School Reform Models, Washington, DC: American Youth Policy Forum.

Perry, W. (1970) Forms of Intellectual and Ethical Development in the College Years: A

Scheme. New York: Holt, Rinehart and Winston.

Saunders, P. (1980) 'The Lasting Effects of Economics Courses' Journal of Economic

Education, vol. 12 (1), pp. 1-14.

Smith, F. (1998) The Book of Learning and Forgetting. New York, NY:Teacher's College Press.

Walstad, W. and Allgood, S. (1999) 'What Do College Seniors Know About Economics?'

American Economic Review, vol. 89 (2), pp. 350-354

Wiggins, G. and McTighe, J. (2005) Understanding by Design, Second Edition, Alexandria, VA: Association for Supervision and Curriculum Development.

Ziegert, A. and McGoldrick, K. (2008) 'When Service is Good for Economics: Linking the Classroom and Community through Service-Learning' International Review of Economics Education, vol. 7(2), pp. 39-56.

Zlotkowski, E. (series ed) (1997-2000) AAHE's Series on Service Learning in the Disciplines. Washington, DC: American Association for Higher Education, miscellaneous volumes.

\section{Contact details}

\section{Janice Peterson}

Department of Economics

California State University, Fresno

Fresno, CA 93740, USA

Tel: $\quad+15592782673$

Email: japeterson@csufresno.edu

KimMarie McGoldrick

Department of Economics

University of Richmond

Richmond, VA 23173, USA

Tel:

+18042898575

Email: kmcgoldr@richmond.edu

\section{Performing Economics: A Critique of 'Teaching and Learning ${ }^{\prime *}$}

David Wilson and William Dixon

\section{Abstract}

Economics students find difficulty in developing effective learning strategies; they would also welcome and benefit from a more pluralistic teaching of economics.

Nevertheless, economics teaching has become less pluralistic over the recent past. Recent benchmark statements seem content to underwrite an essentially monist approach to the discipline in the hope that a deepening crisis in economics teaching can be averted by expanding teaching and learning programmes taking the content of teaching as given and instead concentrating on presentational reform. The paper argues that such teaching and learning strategies are part of the problem rather than its solution.

\section{Introduction}

There has been a tendency in recent years towards the methodologising of economics teaching. By this we mean a tendency to consider the teaching process as a purely presentational issue, so that the how of teaching economics is treated in abstraction from the question as to what should be taught. This is driven in part by the process of quality assurance and partly by the perception that economics is an inherently difficult subject to teach. In addition the focus on teaching has arisen from a previous and equally one-sided focus on 'research' in isolation from, and often at the expense of,'teaching'.

The result of this one-sidedness is the abstraction of 'teaching' from content, and the introduction of dedicated teaching 'experts' and of bureaucratic promotion pathways in teaching. This has led to initiatives that favour 'innovation' in teaching, and to a process by which the separation of the how and the what of economics teaching becomes institutionally embedded in universities; for, while delivery of 